\title{
PEMANFAATAN APLIKASI BERBASIS WEBSITE DALAM AKTIFITAS KAJIAN HARIAN BAGI REMAJA MASJID
}

\section{UTILIZATION OF WEBSITE-BASED APPLICATIONS IN DAILY STUDY ACTIVITIES FOR TEENAGERS}

\author{
Tri Sagirani" ${ }^{\# 1}$, Puspita Kartikasari ${ }^{\# 2}$, Rahayu Arya Shintawati ${ }^{\# 3}$ \\ ${ }^{\# 1}$ Sistem Informasi, Institut Bisnis dan Informatika Stikom Surabaya \\ Jl. Raya Kedung Baruk 98 Surabaya \\ ${ }^{1}$ trisestikom.edu \\ \#2 Statistika, Universitas Diponegoro \\ Jl. Prof. Soedarto, SH Tembalang Semarang \\ ${ }^{2}$ kartikapuspitasari21@gmail.com \\ \#3 Administrasi Perkantoran, Institut Bisnis dan Informatika Stikom Surabaya \\ Jl. Raya Kedung Baruk 98 Surabaya \\ ${ }^{3}$ rahayuestikom.edu
}

\begin{abstract}
Abstrak
Remaja masjid adalah perkumpulan pemuda masjid yang melakukan aktivitas sosial dan ibadah di lingkungan suatu masjid. Remaja masjid juga memiliki tujuan dalam mendukung pembentukan kepribadian dan karakter seorang remaja, salah satunya melalui pembentukan budi pekerti, akhlak mulia, kejujuran, rasa bertanggung jawab dan menghormati orang lain. Remaja masjid mutlak keberadaannya dalam menjamin estafet makmurnya suatu masjid sehingga fungsi dinamika masjid itu sendiri dapat di pertahankan kelangengannya. Pengurus remaja masjid merasa kajian yang dilakukan selama ini masih sangat kurang dari sisi jumlah pertemuan. Pengurus berusaha untuk tetap mengikat ilmu yang dimiliki oleh anggota dalam kesehariannya, maka pengurus Remaja Masjid menginginkan pertemuan rutin yang dapat dilakukan dalam tiap harinya. Dengan bantuan teknologi informasi dan komunikasi harapannya keinginan ini dapat terwujud. Tujuan dari pelaksanakaan kegiatan ini adalah membangun suatu aplikasi berbasis website yang mampu melakukan distribusi materi kajian harian dan mampu melakukan pengukuran terhadap pemahaman materi yang telah dicapai oleh anggota remaja masjid. Target yang diharapkan dari kegiatan ini adalah peningkatan proses pembelajaran ilmu Agama bagi anggota remaja masjid dengan bantuan teknologi informasi dan komunikasi. Terdapat enam tahapan untuk mencapai tujuan yaitu (1) observasi, pengamatan terhadap kebutuhan anggota remaja masjid, (2) penyusunan rencana pembelajaran, (3) penyusunan modul pembelajaran online, (4) penyusunan aplikasi berbasis website, (5) memberikan sosialisasi dan pelatihan kepada pengurus dan anggota remaja masjid, (6) Evaluasi pelaksanaan. Hasil identifikasi pada 135 remaja diperoleh hasil 59,3\% remaja menggunakan aplikasi berbasis website untuk mengenal lebih dalam Ilmu Agama, dan 73,3\% remaja menyatakan membutuhkan aplikasi berbasis website yang dapat mereka gunakan untuk kajian harian dalam mempelajari ilmu Agama secara khusus. Keberhasilan program learning community dengan memanfaatkan aplikasi berbasis website ini dapat diduplikasi untuk komunitas serupa di seluruh wilayah Indonesia.
\end{abstract}

Kata Kunci- aplikasi website, learning community, remaja masjid, kajian harian.

\section{Abstract}

Mosque youth is a group of mosque youths who carry out social activities and worship in a mosque. Mosque youth also have a goal in supporting the formation of the personality and character of a teenager, one of which is through the formation of character, noble character, honesty, a sense of responsibility and respect for others. Teenage mosques have absolute existence in guaranteeing the prosperity of a mosque so that the dynamics of the mosque itself can be preserved. The mosque's youth management felt that the study conducted so far was still lacking in terms of the number of meetings. The caretaker strives to keep the knowledge possessed by members in their daily lives, so the Mosque Youth administrators want regular meetings that can be held on a daily basis. With the help of information and communication technology, it is hoped that this desire can be realized. The purpose of this activity is to build a website-based application that is able to distribute daily study material and be able to measure the understanding of the material that has been achieved by members of the mosque's youth. The expected target of this activity is to improve the learning process of Religion for members of mosque youth with the help of information and communication technology. There are six stages to achieve the objectives, namely (1) observation, observation of the needs of mosque youth members, (2) preparation of learning plans, (3) preparation of online learning modules, (4) preparation of website-based applications, (5) providing outreach and training to mosque management and members, (6) Evaluation of implementation. The results of identification of 135 adolescents obtained $59.3 \%$ of adolescents use website-based applications to get to know more in the Science of Religion, and $73.3 \%$ of adolescents stated that they need a website-based application that they can use for daily studies in studying Religion specifically. The success of the learning community program by utilizing this website-based application can be duplicated for similar communities throughout Indonesia.

Keywords - website application, learning community, mosque youth, daily study. 


\section{PENDAHULUAN}

Masjid merupakan salah satu tempat yang selain berfungsi sebagai tempat ibadah juga sebagai pusat pembinaan akhlak remaja muslim (Kusumawardhani, 2008). Remaja masjid adalah perkumpulan pemuda masjid yang melakukan aktivitas sosial dan ibadah di lingkungan suatu masjid (Aryani, 2015). Remaja masjid juga memiliki tujuan dalam mendukung pembentukan kepribadian dan karakter seorang remaja, salah satunya melalui pembentukan budi pekerti, akhlak mulia, kejujuran, rasa bertanggung jawab dan menghormati orang lain (Badan Penelitian dan Pengembangan, 2010). Hal ini sangat perlu dan mutlak keberadaannya dalam menjamin estafet makmurnya suatu masjid sehingga fungsi dinamika masjid itu sendiri dapat di pertahankan kelangengannya. Salah satu kelompok remaja yang menjadi perhatian peneliti adalah Remaja Masjid Miftahul Ulum yang terletak di Jl. Masjid Tiban, Dusun Daleman, Desa Japan Kecamatan Sooko Kabupaten Mojokerto. Kelompok remaja masjid ini memiliki kegiatan rutin kajian. Sebagai generasi muda muslim, aktivis Remaja Masjid seharusnya mencerminkan muslim yang memiliki keterikatan dengan tempat beribadah umat Islam tersebut. Sikap dan perilakunya islami, sopan-santun dan menunjukkan budi pekerti yang mulia (akhlaqul karimah). Pemikiran, langkah dan tindak-tanduknya dinafasi oleh nilai-nilai Islam. Terdapat beberapa jenis aktivitas Remaja Masjid antara lain berpartisipasi dalam memakmurkan Masjid, melakukan pembinaan remaja muslim, menyelenggarakan proses kaderisasi, memberi dukungan pada penyelenggaraan aktivitas Ta'mir Masjid dan melaksanakan aktivitas da'wah dan sosial (Siswanto, 2005). Untuk mewujudkan aktifitas tersebut Remaja Masjid Miftahul Ulum memiliki pertemuan rutin satu bulan/sekali dalam wadah kajian Islam untuk remaja. Namun oleh pengurus pertemuan ini dirasakan masih sangat kurang dari jumlah pertemuan. Pengurus berusaha untuk tetap mengikat ilmu anggota dalam kesehariannya, maka pengurus Remaja Masjid menginginkan pertemuan rutin yang dapat dilakukan dalam tiap harinya dengan berbantuan teknologi informasi dan komunikasi dan mampu melakukan pengukuran terhadap pemahaman materi yang telah dicapai oleh anggota.

Penguasaan Teknologi Informasi merupakan kecakapan yang juga harus dimiliki oleh setiap anggota remaja masjid. Kecakapan pengetahuan, keterampilan dan sikap termasuk didalamnya kecakapan spiritual perlu dilakukan peningkatan dalam maintenance dari sebulan sekali menjadi setiap hari. Pengurus remaja masjid Miftahul Ulum mengharapkan dapat meningkatkan layanan penyebaran ilmu ini melalui pembentukan komunitas dan melakukan aktifitas pembelajaran berbasis komunitas melalui smartphone dengan mengakses aplikasi WhatsApp dan Website. WhatsApp group selama ini masih digunakan oleh anggota untuk menyebarkan kabar berita, informasi, bahan kajian yang hanya disampaikan begitu saja, sehingga kadang kala terlupakan setelah membacanya.

Peneliti menawarkan solusi untuk permasalahan remaja masjid yang menjadi mitra melalui pembentukan Komunitas yang diberi nama ODOC-Q dengan kepanjangan One Day One Content $Q u$ dan memaksimalkan fungsi whatapps group, aplikasi berbasis website untuk proses pembelajaran (aktifitas learning community). ODOC-Q adalah sebuah komunitas dari remaja masjid yang dibuat untuk mewadahi remaja masjid Miftahul Ulum di Mojokerto sebagai pilot project pada khususnya dan masyarakat muslim yang ingin bergabung pada umumnya. ODOC-Q melakukan aktifitasnya secara online melalui whatsapp group untuk penyebaran materi dan melalui aplikasi berbasis website untuk melakukan absensi melalui quiz harian dan evaluasi. Setiap anggota ODOC-Q berkomitmen untuk mempelajari beberapa ilmu Agama Islam, yang telah disiapkan dalam sebuah kurikulum khusus. ODOC-Q mengikat komitmen setiap anggotanya, untuk melakukan pembelajaran dalam setiap harinya, dan melalukan quiz harian, Evaluasi periode mingguan dan Evaluasi periode bulanan, hingga dinyatakan lulus dan dapat melanjutkan ke tingkatan berikutnya. Quiz harian dilakukan setiap hari mulai hari senin sampai jum'at dengan mengerjakan satu soal, ini berlaku juga untuk proses absensi harian. Evaluasi periode mingguan dilakukan setiap akhir pekan dengan mengerjakan lima soal dan evaluasi bulanan dilakukan dengan mengerjakan 20 soal. Hasil dari quiz harian dan evaluasi akan menentukan kelulusan setiap anggota remaja masjid untuk dapat melanjutkan ke tingkatan berikutnya. Setiap remaja masjid yang berhasil melalui tingkatan tertentu akan diterbitkan sahadah (sertifikat) dan juga transkrip nilai.

\section{TARGET DAN LUARAN}

Target serta capaian luaran dari program ini kesemuanya untuk meningkatkan dan mengoptimalkan proses pembelajaran ilmu Agama bagi anggota remaja masjid.

\section{A. Target yang ingin dicapai}

1. Identifikasi dukungan TIK yang dibutuhkan oleh pengurus remaja masjid

2. Penyusunan kurikulum/ materi/ konten harian 
3. Digitalisasi materi pembelajaran, data anggota dan data pengurus.

4. Pemanfaatan aplikasi untuk proses pembelajaran yang memiliki fitur:

a. Melakukan distribusi materi sesuai jadwal melalui Whatsapp group

b. Menampilkan soal quis harian, evaluasi mingguan dan bulanan

c. Menghitung hasil nilai dari quis harian, evaluasi mingguan dan bulanan

d. Menentukan kenaikan tingkat dari anggota ke level materi berikutnya

e. Menerbitkan sahadah/ sertifikat dan transkrip nilai

\section{B. Luaran yang dihasilkan}

1. Rancangan kurikulum pembelajaran Agama Islam

2. Seperangkat aplikasi pembelajaran Agama Islam online bagi Komunitas Remaja Masjid

3. Modul pelatihan penggunaan aplikasi bagi pengurus remaja masjid yang ditugaskan menjadi administrator dari aplikasi ODOC-Q

4. Publikasi ilmiah

\section{METODE PELAKSANAAN}

Metode pelaksanaan untuk menjawab permasalahan remaja masjid Miftahul Ulum dijelaskan dalam empat pokok bahasan yaitu metode pendekatan, pelaksanaan program, partisipasi mitra dan evaluasi berkelanjutan.

\section{A. Metode Pendekatan}

Metode pendekatan yang ditempuh untuk melaksanakan program ini adalah sebagai berikut :

1. Observasi, pengamatan terhadap kebutuhan anggota remaja masjid dalam mengoptimalkan pembelaran Agama Islam

2. Penyusunan rencana pembelajaran

3. Menyusun modul pembelajaran online berbasis whatsapp group dan aplikasi berbasis website

4. Penyusunan Aplikasi berbasis website responsive dengan fitur distribusi materi, quiz harian, evaluasi mingguan dan bulanan, penentuan kelulusan, dan cetak sertifikat dan transkrip nilai

5. Memberikan pelatihan kepada pengurus dan anggota remaja masjid

6. Evaluasi

\section{B. Pelaksanaan Program}

Sesuai dengan metode pendekatan yang disampaikan berikutnya adalah pelaksanaan program yang telah disusun. Tabel 1 berikut ini adalah daftar kegiatan lengkap dengan kriteria dan indikator keberhasilan dalam pencapaian tujuan.
TABEL I

PELAKSANAAN KEGIATAN

\begin{tabular}{|c|c|c|}
\hline Kegiatan & Kriteria & $\begin{array}{c}\text { Indikator } \\
\text { Keberhasilan }\end{array}$ \\
\hline $\begin{array}{l}\text { Observasi, } \\
\text { pengamatan } \\
\text { terhadap } \\
\text { kebutuhan } \\
\text { anggota remaja } \\
\text { masjid }\end{array}$ & $\begin{array}{l}\text { Tersusun } \\
\text { daftar } \\
\text { kebutuhan } \\
\text { pengurus dan } \\
\text { anggota } \\
\text { remaja masjid } \\
\text { sebagai mitra. }\end{array}$ & $\begin{array}{l}\text { Kebutuhan mitra } \\
\text { dapat teridentifikasi } \\
\text { dalam bentuk list } \\
\text { daftar kebutuhan }\end{array}$ \\
\hline $\begin{array}{l}\text { Penyusunan } \\
\text { rencana } \\
\text { pembelajaran }\end{array}$ & $\begin{array}{l}\text { Tersusun } \\
\text { rencana dan } \\
\text { modul } \\
\text { pembelajaan }\end{array}$ & $\begin{array}{l}\text { Rencana } \\
\text { pembelajaran dapat } \\
\text { dijalankan oleh } \\
\text { mitra }\end{array}$ \\
\hline $\begin{array}{l}\text { Menyusun } \\
\text { modul } \\
\text { pembelajaran } \\
\text { online baik } \\
\text { berbasis } \\
\text { whatsapp } \\
\text { group, aplikasi } \\
\text { berbasis } \\
\text { website }\end{array}$ & $\begin{array}{l}\text { Tersusun } \\
\text { modul } \\
\text { pembelajaran } \\
\text { online untuk } \\
\text { group } \\
\text { WhatsApp, } \\
\text { aplikasi } \\
\text { berbasis } \\
\text { website }\end{array}$ & $\begin{array}{l}\text { Modul } \\
\text { pembelajaran dapat } \\
\text { dijalankan oleh } \\
\text { mitra }\end{array}$ \\
\hline $\begin{array}{l}\text { Penyusunan } \\
\text { Aplikasi } \\
\text { dengan fitur } \\
\text { distribusi } \\
\text { materi, quiz } \\
\text { harian, evaluasi } \\
\text { mingguan dan } \\
\text { bulanan, } \\
\text { penentuan } \\
\text { kelulusan, dan } \\
\text { cetak sertifikat } \\
\text { dan transkrip } \\
\text { nilai }\end{array}$ & $\begin{array}{l}\text { Tersusun } \\
\text { aplikasi yang } \\
\text { memiliki } \\
\text { fitur : } \\
\text { - distribusi } \\
\text { materi, quiz } \\
\text { harian, } \\
\text { - evaluasi } \\
\text { mingguan } \\
\text { dan bulanan, } \\
\text { penentuan } \\
\text { kelulusan, } \\
\text { - cetak } \\
\text { sertifikat dan } \\
\text { transkrip nilai }\end{array}$ & $\begin{array}{l}\text { Operasional } \\
\text { harian dari } \\
\text { remaja masjid } \\
\text { dapat } \\
\text { dikendalikan } \\
\text { dengan } \\
\text { pemanfaatan } \\
\text { aplikasi } \\
\text { komputer }\end{array}$ \\
\hline $\begin{array}{l}\text { Memberikan } \\
\text { pelatihan } \\
\text { kepada } \\
\text { pengurus dan } \\
\text { anggota remaja } \\
\text { masjid }\end{array}$ & $\begin{array}{l}\text {-Tersusun } \\
\text { daftar materi } \\
\text { pelatihan } \\
\text {-Terlaksana } \\
\text { pelatihan bagi } \\
\text { pengurus dan } \\
\text { anggota }\end{array}$ & $\begin{array}{l}\text { Proses } \\
\text { pembelajaran } \\
\text { berjalan lancar }\end{array}$ \\
\hline Evaluasi & $\begin{array}{l}\text { Tersusun } \\
\text { sesuai Buku } \\
\text { Panduan }\end{array}$ & $\begin{array}{l}\text { Tersusun } \\
\text { evaluasi/ } \\
\text { laporan, dan } \\
\text { juga publikasi } \\
\text { hasil }\end{array}$ \\
\hline
\end{tabular}

\section{Partisipasi Mitra}

Mitra sangat mendukung dan berpartisipasi penuh terhadap jalannya program kegiatan yang telah direncanakan bersama secara aktif. Adapun partisipasi tersebut adalah :

1. Memberikan dukungan data-data anggota remaja masjid aktif

2. Memberikan sarana untuk berdiskusi tentang rencana pembelajaran dan bahan materi 
3. Menyediakan kebutuhan infrastruktur untuk pengurus remaja masjid dalam menggunakan aplikasi dan menjalankan tugas

4. Menyediakan sarana pendukung berupa kelas yang memadai untuk keperluan pelatihan dan pembelajaran

5. Berperan aktif memberikan masukan-masukan yang terkait dengan penyusunan rencana pembelajaran dan penyusunan website dan group whatsapp

\section{Evaluasi Berkelanjutan}

Guna melakukan evaluasi berkelanjutan terhadap program ini maka telah disepakati bersama mitra bahwa akan dilakukan komunikasi untuk proses berlangsungnya pembelajaran selanjutnya. Mitra akan melaksanakan program ini secara berkelanjutan dengan mengikuti rencana pembelajaran dan modul pembelajaran yang telah disusun.

\section{IV.HASIL DAN PEMBAHASAN}

Kegiatan PKM ini menghasilkan luaran yang dapat dimanfaatkan oleh pengurus dan anggota remaja masjid dalam melakukan kajian harian, dimanapun mereka berada dan kapanpun dalam aktifitas harian mereka. Identifikasi terhadap kebutuhan pada remaja masjid ini dilakukan pada 135 remaja. Statistika Deskriptif Responden dilakukan untuk melihat bagaimana karakteristik responden dalam hal ini adalah remaja masjid yang memanfaatkan aplikasi berbasis website. Responden diklasifikasikan jumlahnya berdasarkan jenis kelamin, keaktifan dalam kegiatan keagamaan, dan pemanfaatan aplikasi untuk mendukung kegiatan keagamaan. 106 remaja $(78.5 \%)$ remaja dari responden berjenis kelamin laki-

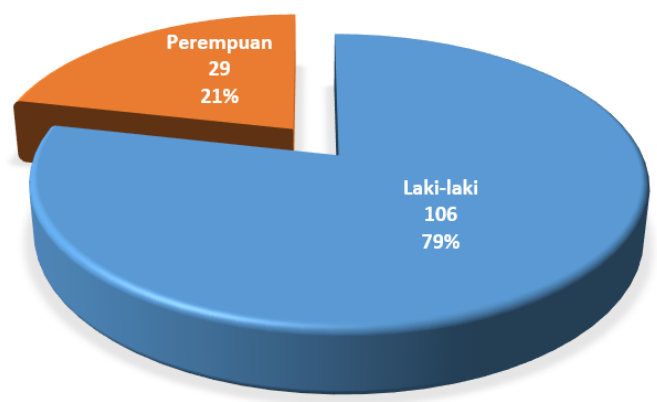

laki, sedangkan sisanya sebanyak $29(21.5 \%)$ remaja dari responden berjenis kelamin perempuan.

Gambar 1 Responden Berdasarkan Jenis Kelamin

Dari 135 remaja yang menjadi responden, sebanyak 79 remaja menyatakan aktif dalam kegiatan keagamaan yang dilaksanakan di masjid setempat ataupun di wilayah RT/RW tempat dia tinggal.

Selanjutkan dilakukan pengukuran persentasi remaja yang memanfaatkan aplikasi website dan yang merasa membutuhkan aplikasi website untuk lebih mendalami ilmu Agama. Gambar 2 berikut ini menjelaskan bahwa 59,3 \% remaja yang menjadi responden menyatakan memanfaatkan aplikasi website untuk menunjang aktifitas keagamaan dan 73,3\% menyatakan membutuhkan aplikasi berbasis website untuk memperdalam ilmu agama.

Pemanfaatan Aplikasi

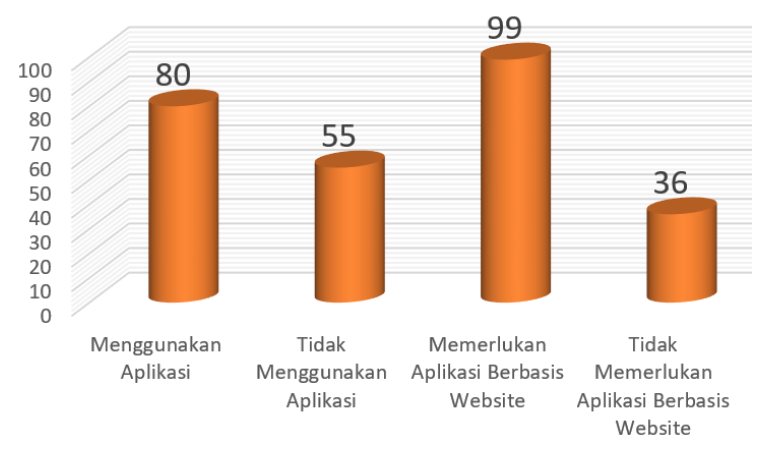

Gambar 2 Responden Berdasarkan Pemanfaatan Aplikasi

Dari data diatas maka remaja masjid masih membutuhkan aplikasi berbasis website untuk mendukung kajian harian yang dapat mereka lakukan secara rutin di berbantuan aplikasi berbasis website. Telah dilakukan serangkaian kegiatan untuk menjawab kebutuhan ini, hingga pada akhirnya membangun sebuah sistem untuk mendukung dan menjadi solusi bagi aktifitas remaja masjid. Berikut ini adalah tampilan dari rancangan user interface aplikasi berbasis website yang dikembangkan untuk

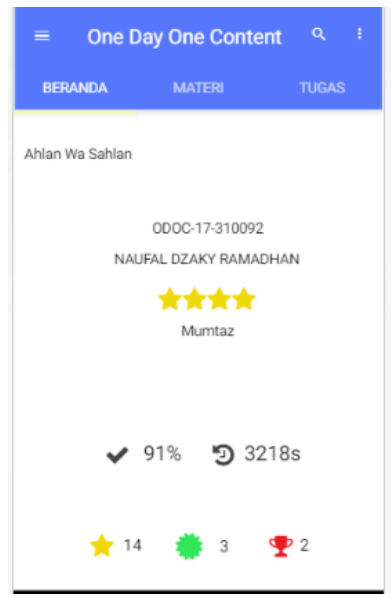

mendukung kegiatan remaja masjid.

Gambar 3 Tampilan User Interface untuk Halaman Utama

Gambar 3 diatas adalah tampilan halaman utama memuat kode anggota, nama anggota berikut perolehan bintang, medali dan trophy yang didapat dari hasil penilaian dalam aktifitas kajian harian.

Gambar 4 Tampilan User Interface untuk Halaman Beranda 


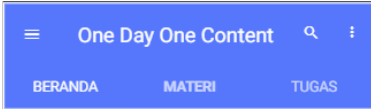

Tampilan halaman beranda pada Gambar 4 menampilkan menu-menu yang dapat digunakan oleh anggota remaja masjid dalam melakukan aktifitas kajian harian. Halaman ini berisi pembagian materi berupa dokumen/ teks, audio, tanya jawab dan kurikulum yang telah disediakan untuk proses pembelajaran.

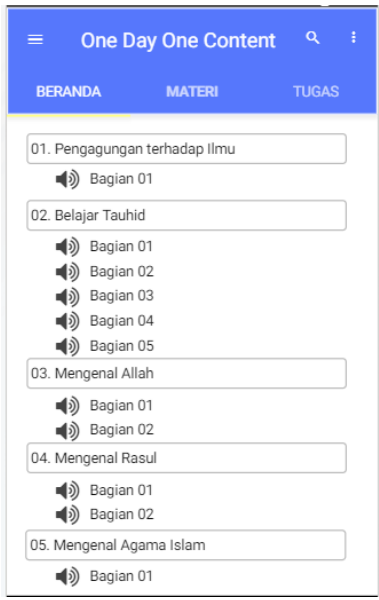

Gambar 5 Tampilan User Interface untuk Halaman Materi

Gambar 5 adalah tampilan halaman materi menampilkan materi berupa dokumen/ teks dan audio yang dapat digunakan untuk anggota remaja masjid. Materi disediakan sesuai dengan kurikulum dan pembagian materi yang ada. Remaja masjid tinggal memilih materi yang akan dipelajari baik yang berbentuk teks maupun yang berformat audio.

Tampilan selanjutnya yang juga dibutuhkan adalah halaman tugas seperti dalam Gambar 6 yang menampilkan menu untuk mengerjakan tugas harian, melihat perolehan hasil/ nilai tugas, poin yang didapatkan anggota, perkembangan hasil, peringkat dalam kelompok dan arsip tugas yang menyimpan tugas-tugas yang telah dilaksanakan oleh anggota berikut dengan informasi jawaban yang tepat.

\section{Gambar 6 Tampilan User Interface untuk Halaman Tugas}

Tampilan halaman mengerjakan tugas harian menampilkan daftar pertanyaan, pilihan jawaban dan timer yang berjalan/ menghitung mundur. Setiap anggota diharuskan mengerjakan setiap soal yang ada dalam halaman tugas ini sebelum waktu yang disediakan habis. Hasil dari tugas akan disampaikan setelah anggota mengirim jawabannya. Hasil/ nilai ini akan dievaluasi untuk setiap anggota dan ditampilkan rangking dari anggota mulai dari hasil yang tertinggi.

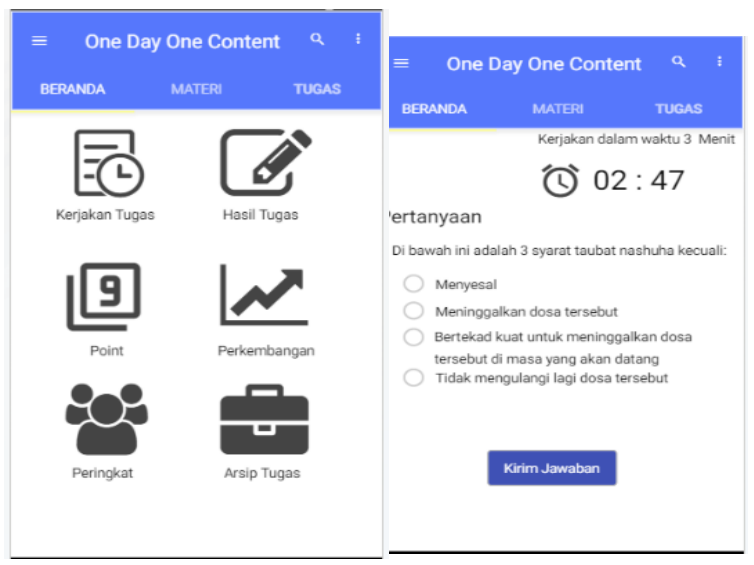

Gambar 7 Tampilan User Interface untuk Halaman Mengerjakan Tugas

Aplikasi berbasis website yang disusun dalam pelaksanaan pembelajaran, dikolaborasikan dengan pemanfaatan group what app untuk memperingatkan anggota remaja masjid untuk mulai menyimak materi harian dan juga mengerjakan tugas/ evaluasi harian. Peringatan ini dikirimkan melalui group what app setiap pagi hari untuk memperingatkan bahwa materi siap untuk disimak, dan pada sore harinya peringatan kembali dikirimkan melalui group what app untuk informasi bahwa tugas harian siap dikerjakan.

Gambar 8 berikut ini adalah isi pesan yang dikirim oleh pengelola/ pengurus remaja masjid untuk anggota sebagai pertanda bahwa materi telah tersedia baik di group what app maupun di aplikasi berbasis website.

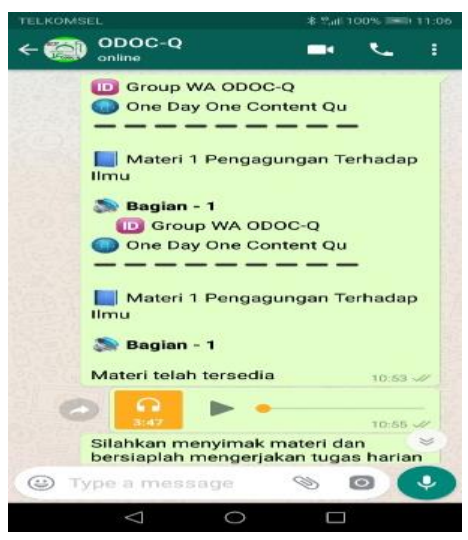

Gambar 8 Tampilan Group What App untuk materi

Gambar 9 adalah isi pesan yang dikirim oleh pengelola/ pengurus remaja masjid untuk anggota 
sebagai peringatan bahwa pengerjaan tugas/ evaluasi sudah dibuka.

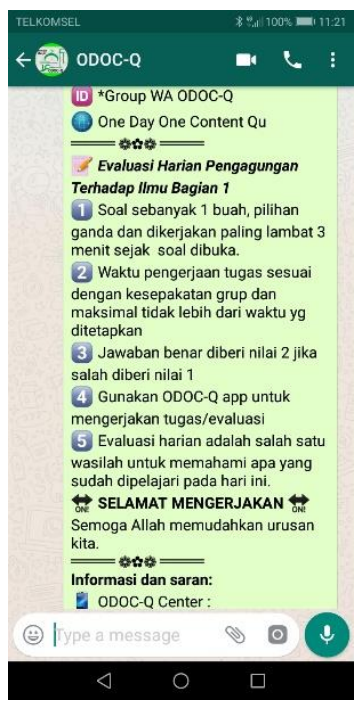

Gambar 9 Tampilan Group What App untuk Tugas/ Evaluasi

Aktifitas dalam penyusunan dan implementasi aplikasi berbasis website terlihat pada foto-foto kegiatan berikut ini. Gambar 10 berikut ada pertemuan tim inti PKM dalam merumuskan rencana kegiatan yaitu identifikasi dari kebutuhan mitra, menyusun kurikulum, menentukan bentuk user interface dari aplikasi berbasis website yang disusun dan rencana evaluasi berkelanjutan bersama mitra.

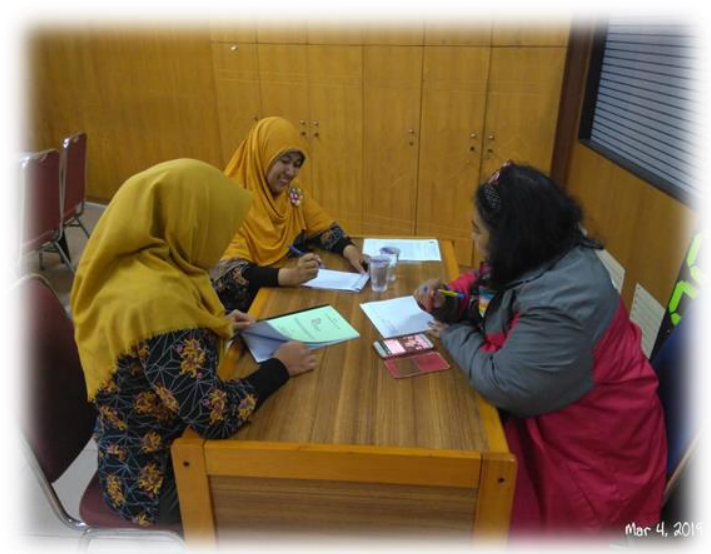

Gambar 10 Koordinasi Penyusunan Rencana kegiatan

Dokumentasi dari pelaksanaan kegiatan berikutnya adalah mengumpulkan data untuk identifikasi kebutuhan dari remaja masjid untuk mengembangan aplikasi berbasis website. Gambar 11 berikut adalah aktifitas identifikasi kebutuhan pengguna dengan memanfaatkan aplikasi online dan wawancara secara langsung.
Gambar 11 Analisa Kebutuhan Pemanfaatan Aplikasi

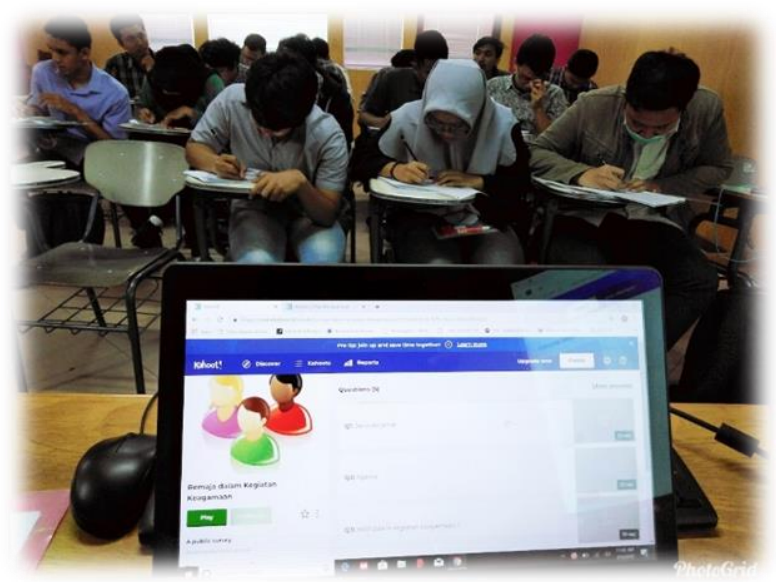

Aktifikas PKM berikutnya adalah kegiatan sosialisasi program kepada remaja masjid, tentang pemanfaatan aplikasi berbasis website untuk mendukung aktifitas kajian harian yang akan mereka ikuti. Solusi yang ditawarkan bagi remaja masjid ini adalah pemanfaatan aplikasi untuk proses pembelajaran yang memiliki fitur: dapat melakukan distribusi materi sesuai jadwal melalui Whats app group, menampilkan soal quis harian, evaluasi mingguan dan bulanan melalui aplikasi berbasis website, menghitung hasil nilai dari quis harian, evaluasi mingguan dan bulanan dan dapat menunjukkan perkembangan hasil belajar. Gambar 12 berikut ini adalah dokumentasi kegiatan sosialisasi program kepada remaja masjid.

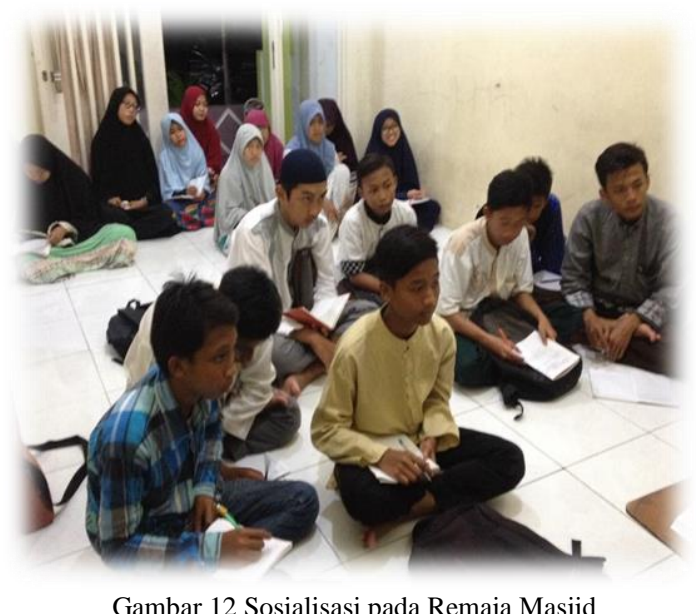

Gambar 13 berikut ini adalah dokumentasi kegiatan berikutnya yaitu ujicoba terbatas bersama tim pengembang dan perwakilan remaja. 


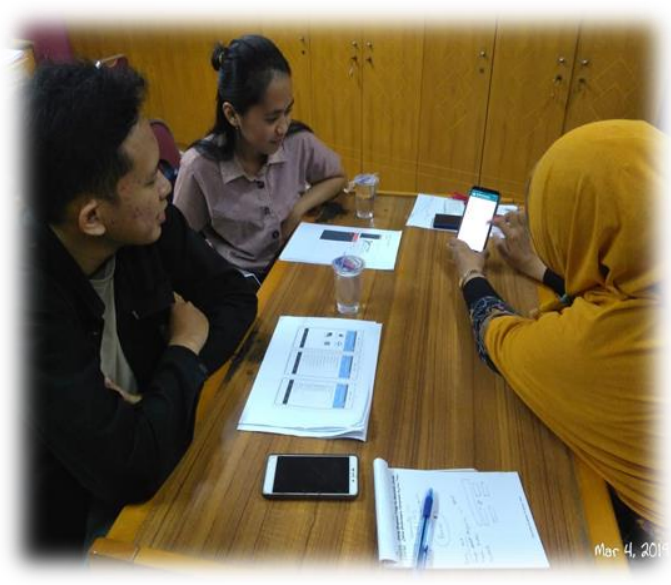

Gambar 13 Ujicoba Terbatas dengan Pengembang

Aplikasi ini selanjutnya digunakan oleh remaja masjid dan pada akhirnya dapat memudahkan pengurus dan anggota remaja masjid untuk mengelola kegiatan kajian harian dimanapun mereka berada dan kapanpun. Anggota remaja masjid dapat melakukan update pengetahuan dibidang ilmu Agama sesuai dengan kurikulum yang telah disusun. Bagi pengurus harapan untuk dapat memajukan kemampuan dan pemamahan anggota di bidang keagamaan dan meningkatkan kebermanfaatan perangkat komunikasi dalam pembelajaran.

Adapun aktifitas

\section{KESIMPULAN}

Kegiatan PKM berupa pemanfaatan Aplikasi Berbasis website dalam Aktifitas Kajian Harian Remaja Masjid ini diawali dengan melakukan identifikasi kepada remaja tentang kebutuhan terhadap pemanfaatan aplikasi untuk kajian harian melaui perangkat komunikasi yang mereka miliki, dan didapatkan hasil dari 135 remaja 73,3\% remaja menyatakan membutuhkan aplikasi berbasis website yang dapat mereka gunakan untuk kajian harian secara rutin dan juga untuk meningkatkan pemahaman dalam mendalami ilmu Agama. Hasil lain yang didapat adalah terbagun sebuah aplikasi berbasis website untuk mendukung pengurus remaja masjid untuk menyelenggarakan kajian secara rutin untuk remaja masjid yang dilakukan melalui peralatan komunikasi yang telah dimiliki oleh setiap anggotanya. Keberhasilan program PKM dengan memanfaatkan aplikasi berbasis website ini dapat diduplikasi untuk komunitas serupa di seluruh wilayah Indonesia. Pengembangan terhadap teknologi yang digunakan juga dapat dilakukan, yaitu dengan mengembangkan aplikasi menjadi berbasis Android.

\section{UCAPAN TERIMA KASIH}

Tim pengabdian masyarakat mengucapkan terima kasih kepada Direktorat Riset dan Pengabdian Kepada masyarakat, Kementrian Riset, Teknologi, dan Pendidikan Tinggi yang telah memberikan kesempatan kepada peneliti dalam menjalankan kegiatan ini melalui Program kemitraan Masyarakat (PKM). Ucapan terimakasih juga kepada segenap pimpinan dan jajaran Institut Bisnis dan Informatika Stikom Surabaya atas fasilitas yang telah disediakan untuk mendukung keberhasilan jalannya PKM ini, dan tidak lupa untuk seluruh pengurus dan anggota Remaja Masjid yang telah berkenan menjadi mitra dalam implementasi program ini.

\section{DAFTAR PUSTAKA}

[1] Aryani, D., 2015. Masjid dan Perubahan Sosial (Kajian tentang aktivitas Masjid Baitur Rahman terhadap perubahan sosial masyarakat perumahan polri gowok, sleman, yogyakata). Fak. Ilmu Sosial dan Humaniora, UIN Sunan Jalijaga, Yogjakarya,

[2] Kementerian Pendidikan Nasional, 2010. Pengembangan Pendidikan Budaya Dan Karakter Bangsa. Jakarta: Badan Penelitian dan Pengembangan Pusat Kurikulum Kemendiknas

[3] Kusumawardhani, N., 2008. Masjid sebagai Pusat Pembinaan Akhlak Remaja. Fak. Ilmu Tarbiyah dan Keguruan, UIN Sunan Jalijaga, Yogjakarya

[4] Siswanto, 2005, Panduan Praktis Organisasi Remaja Masjid, Jakarta: Pustaka Al Kautsa 